\title{
Lingulate brachiopods across the Kačák Event and Eifelian-Givetian boundary in the Barrandian area, Czech Republic
}

\author{
Michal Mergl
}

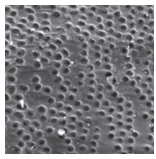

\begin{abstract}
Dark limestone interval of the late Eifelian (Polygnathus ensensis Zone) from the Koněprusy area in the Czech Republic yielded rare but remarkable organophosphatic brachiopod fauna, with the last-appearance datum of genera Paterula Barrande, 1879 and Orbaspina Valentine \& Brock, 2003 in the fossils records. The first-appearance datum of the genus Lingulipora Girty, 1898 (represented by the L. budili sp. nov.) has been observed in the late Eifelian (Tortodus kockelianus Zone) yet below the dark limestone interval. New microbrachiopod Opsiconidion nanus sp. nov. and striking unnamed biernatiid are described from the upper Acanthopyge Limestone. Organophosphatic brachiopods confirm dramatic environmental changes at the latest Eifelian in the Barrandian. Demonstration of the Kačák Event (Polygnathus ensensis Zone) led to expansion of oxygen reduced environment over preceding shallow-water carbonate elevation. The expansion draws out the deep water and hypoxic (Orbaspina, Paterula) and likely epiplanktonic (Opatrilkiella Mergl, 2001a, Opsiconidion Ludvigsen, 1974) brachiopods over formerly much shallower environment. The Kačák anoxic Event likely triggered the Givetian to Famennian expansion of Lingulipora over the shelves of Laurussia palaeocontinent. - Key words: Lingulata, Discinoidea, Siphonotretida, Eifelian, Kačák Event, taxonomy, Koněprusy, Barrandian.
\end{abstract}

\begin{abstract}
Mergl, M. 2019. Lingulate brachiopods across the Kačák Event and Eifelian-Givetian boundary in the Barrandian area, Czech Republic. Bulletin of Geosciences 94(2), 169-186 (8 figures). Czech Geological Survey, Prague. ISSN 1214-1119. Manuscript received January 1, 2019; accepted in revised form April 4, 2019; published online May 10, 2019; issued June 17, 2019.
\end{abstract}

Michal Mergl, Faculty of Environmental Sciences, Czech University of Life Sciences Prague, Kamýcká 129, 16521 Praha 6-Suchdol, Czech Republic; Argyrotheca@seznam.cz

The Koněprusy area in the SW part of the Silurian-Devonian marine sedimentary succession of the Barrandian area in Central Bohemia is a classic area of the Devonian stratigraphy and palaeontology. It is the famous, rich and unique source of diverse and well-preserved fossils for more than one-and-half century (e.g. Barrande 1847, 1848,1852 , 1879). Palaeontology and history of its investigation research was reviewed many times (Chlupáč 1984, 1996, 2003 and reference herein). The present concept of stratigraphy of the Devonian sediments at Koněprusy is based on series of early studies of Chlupáč $(1955,1956,1957,1959)$ supplemented by contributions devoted to various aspects of this unique area (Chlupáč 1983, 1996, 2003; Hladil 1995).

The youngest lithostratigraphic unit preserved as erosional remnant in the Koněprusy area are calcareous sandstones and shales having poor remains of terrestric flora referred to the Roblín Member of the Srbsko Formation (uppermost Eifelian to ?Givetian) (Svoboda \& Prantl 1949; Kukal \& Jäger 1988; Chlupáč 1998a, 2003). In the recently protected geological site at abandoned
Jirásek's Quarry (Fig. 1), the small outcrop with unique contact of the Acanthopyge Limestone (Eifelian) with the Srbsko Formation (Givetian) was studied by Hladil et al. (1991, 1992). The youngest marine macrofauna has been observed in the limestone bed 46 above $c a$. $0.7 \mathrm{~m}$ thick interval of dark limestone (UDI: Upper dark interval = bed 45 after Hladil et al. 1991). Tabulatomorphs and stromatoporoids dominated by Caliapora ex gr. battersbyi (Milne-Edwards \& Haime, 1851) from the bed 46 indicate the Eifelian-Givetian boundary interval (Hladil 1993). The UDI is correlated with the shallow water to slope equivalent of shales of the Kačák Member, Srbsko Formation. The UDI is single available section in which Eifelian-Givetian boundary is developed in a carbonate succession in the Barrandian. The fauna of UDI is poorly known, only conodonts, dacryoconarids and microvertebrates were determined. The shelly fossils are generally rare and extremely fragmental. Presence of bryozoans, brachiopods, trilobites, ostracods, foraminifers, and crinoids has been stated, but these groups were not studied so far (Hladil et al. 1991, 1992; Budil 1995). 


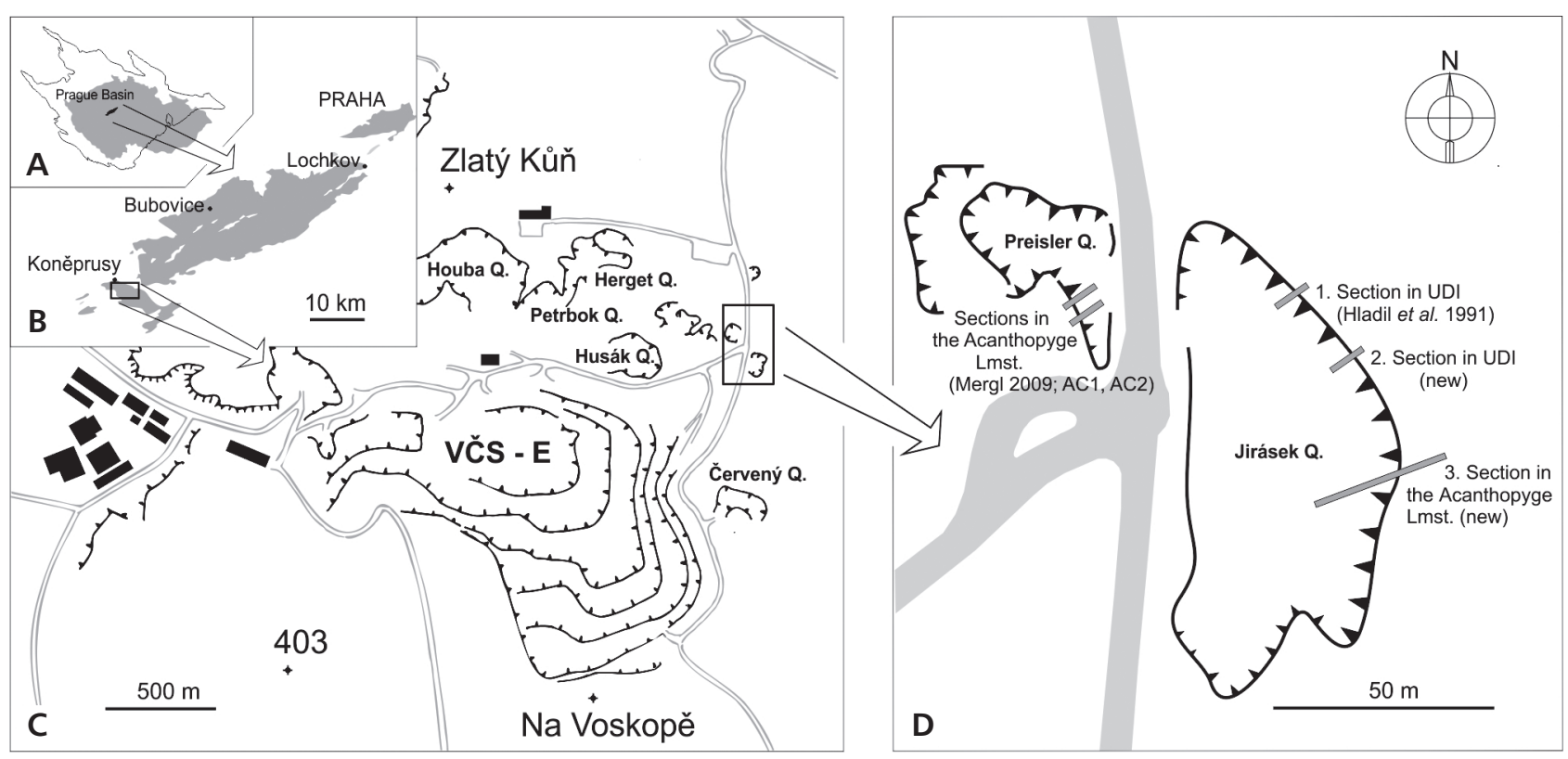

Figure 1. A - schematic map showing location of the Prague Basin in the Barrandian area in the Czech Republic. $\bullet \mathrm{B}-$ the Koněprusy area. $\bullet \mathrm{C}$ - quarries in the Koněprusy area. • D - Jirásek's Quarry and Preisler's Quarry. The exact location of the section (1) described by Hladil (1993); sections AC1, AC2 by Mergl (2008); and two new sections from which the brachiopods were extracted $(2,3)$ are figured. Abbreviations: UDI - upper dark interval; VČS-E - Velkolom Čertovy schody - východ Quarry.

New extensive sampling for phosphatic fossils indicates moderate diversity of organophosphatic brachiopods. Although brachiopod shells are rare and extremely fragmental, several taxa are worth present for their stratigraphical significance. Therefore all observed taxa are described and, when possible, illustrated.

\section{Geological setting}

The Prague Basin is small part of the former Early Palaeozoic basin located on periphery of the Gondwana. The Devonian units of the basin together with the older Palaeozoic and Proterozoic units form the crustal block called the Barrandian (or Teplá-Barrandian Terranne). This crustal block has been differently interpreted but most likely represents one of peri-Gondwannan terranes (Havlíček et al. 1994, Cocks \& Torsvik 2002, Stampfli et al. 2002, Žák \& Sláma 2018).

The Devonian sequence of the Prague Basin follows the underlying Silurian formations (Chlupáč et al. 1998b). Apart of the Daleje Shale (Emsian) and latest Srbsko Formation (latest Eifelian to Givetian), the Devonian sediments are distinguished by carbonate development. The shallow submarine elevation prolific in benthic fauna developed in the Lochkovian (Kotýs Limestone) in the Koněprusy area. In the Pragian, the coral reef originated at the same place. The reef fringed extremely diverse peri-reefal mainly brachiopod-bryozoan-crinoid benthic associations (Koněprusy Limestone) which continues basinward to moderately deeper environment (Vinařice, Řeporyje and Slivenec limestones). These abound with diverse microcrinoids, small-shelled brachiopods and other mostly small sized benthic and pelagic fossils including the dacryoconarids. After a short emergence and erosion of the reef in late Pragian and early Emsian, the shallow marine environment reappeared in the Koněprusy area in late Emsian (Suchomasty Limestone) and continued to the Eifelian (Acanthopyge Limestone). The latest history of the reef complex is less apparent due to the post-Devonian erosion. The most likely, the carbonate production competed after the episode of moderate deepening near the Emsian-Givetian boundary interval entailed by the Kačák Event. The siliciclastic deposits of the Roblín Member (Srbsko Formation) indicate the beginning of the sea retreat from the Prague Basin (Chlupáč 1998b and references herein).

Limestones of the Eifelian age are restricted to small area in the Koněprusy Village vicinity. Apart of the summit of Zlatý Kůn̆ Hill, the Acanthopyge Limestone and younger strata form the narrow strip between the entry to the Koněprusy Cave and Zadní Kobyla Hill. There are numerous small quarries, pits and small outcrops, but their stratigraphic correlation is not clear for weak folding, faulting, and by cover of detritus, soil and vegetation (Hladil et al. 1991, 1992). The most complete sequence of the upper part Acanthopyge Limestone is situated in the $\mathrm{N}$ wall of the abandoned Jirásek's Quarry (also known as Acanthopyge Quarry). The newly measured section comprises roughly $10 \mathrm{~m}$ thick sequence of gently dipping 
limestone beds of the upper part of the Acanthopyge Limestone, which continues (with small break due covering by trees; Fig. 2) to by $0.7 \mathrm{~m}$ thick "upper dark interval" followed by $2.5 \mathrm{~m}$ thick sequence of limestone and shale strata. This $2.5 \mathrm{~m}$ thick sequence was referred by Hladil et al. (1992) to the Srbsko Formation.

The Acanthopyge Limestone of the Choteč Formation is approximately $20 \mathrm{~m}$ thick (Chlupáč 1998b) unit of
Eifelian age. This local unit occurs only at the Koněprusy area but some of its typical trilobite species were observed at Hostim outside the Koněprusy area (Chlupáč 1983, 2003). It is built of light grey platy to thick-bedded bioclastic, mostly crinoidal limestones, with lenses of biomicrites, laminated micrites, and coarse bioclastic breccia (Havlíček \& Kukal 1990, Chlupáč 1998b). The fauna of the Acanthopyge Limestone is famous for rugose
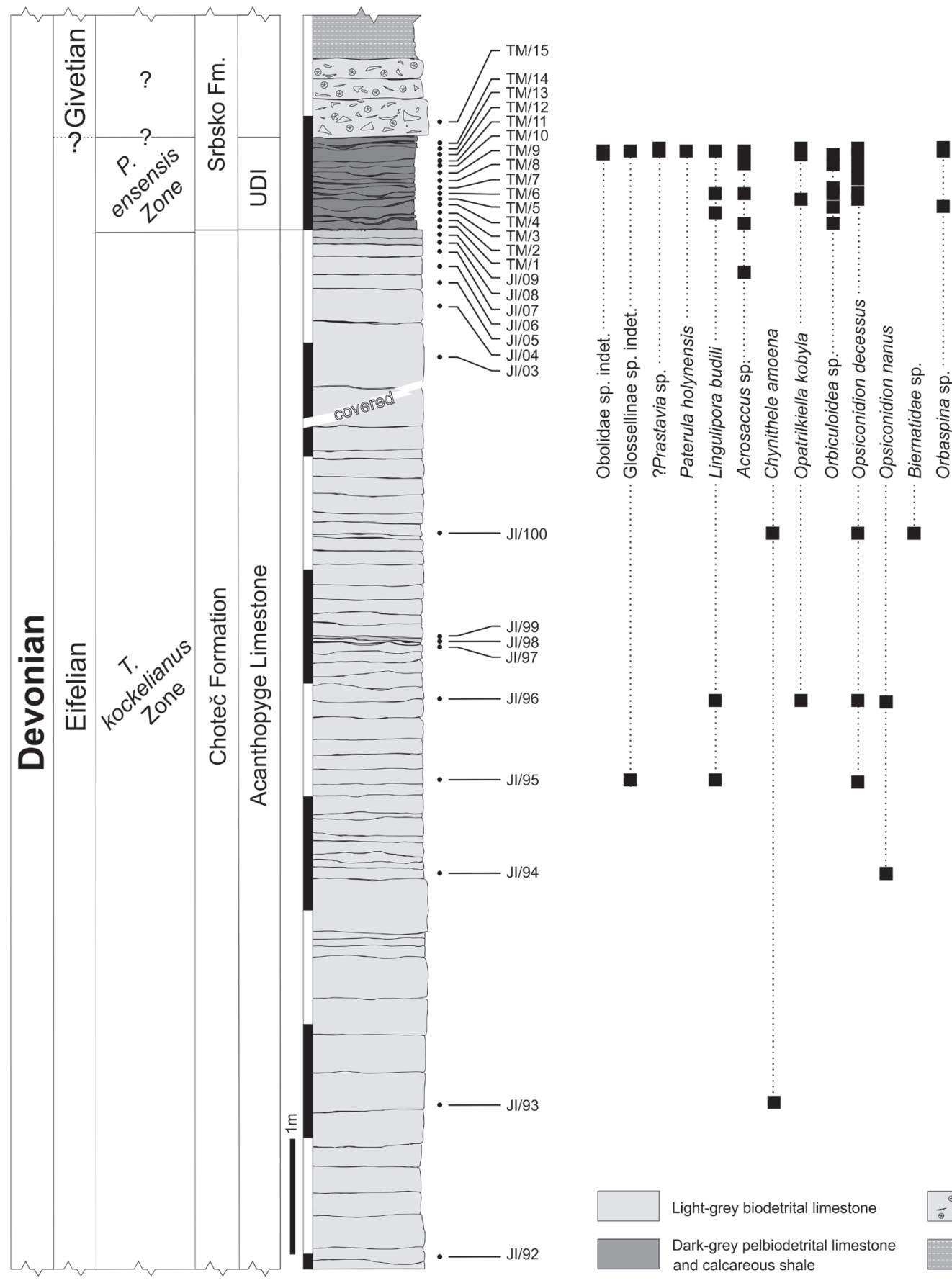

Figure 2. Studied section in the Jirásek's Quarry with basic data on lithology, samples, and stratigraphical distribution of organophosphatic brachiopod species. 
corals, tabulates, stromatoporoids, trilobites, cephalopods and smooth-shelled brachiopods with subordinate other invertebrate groups (see Havlíček \& Kukal 1990; Galle 1994; Chlupáč 1998b; Mergl 2008, 2014, 2015). Conodonts demonstrate Polygnathus partitus to P. ensensis zones (Zikmudová \& Kalvoda in Galle \& Hladil 1991, Kalvoda 1992).

In the Barradian, the Kačák Member of the Srbsko Formation is 2 to $15 \mathrm{~m}$ thick unit of dark-grey thinly laminated calcareous shales and cherts. The fauna show dominance of pelagic invertebrates including the radiolarians (Bouček 1964, Chlupáč \& Turek 1983, Budil 1995) although relics of land plants are frequent (Obrhel 1961, 1968). However, at the Koněprusy area, the Kačák Member is not typically developed. The dark interval with abundant dacryoconarids, poor benthic fauna and plant remains above the eroded beds of the Acanthopyge Limestone at the Jirásek's Quarry section was by Hladil et al. (1991, 1992), Kalvoda (1992), Galle (1994) and Budil (1995) assumed the time-equivalent of the Kačák Event. Hladil et al. (1992) and Hladil (1993, p. 33) correlated the UDI as a shallower water to slope equivalent with the deeper Kačák shales.

Few fossils were reported from the UDI at Jirásek's Quarry. Conodonts (Zikmundová \& Kalvoda in Galle \& Hladil 1991, Kalvoda 1992), microvertebrates (Mergl et al. 2017) of the bed 45 have been studied, and dacryoconarids Nowakia (Cepanowakia) pumilio (Alberti, 1978), Nowakia ex. gr. otomari Bouček \& Prantl, 1959, Styliolina ?fissurella Hall, 1843, Lukesia elixi Berkyová, 2004 and ?Metastyliolina sp. were determined (Hladil et al. 1992, Budil 1995, Berkyová 2004). Rare brachiopods and trilobites were tentatively referred to Nymistrophia [sic!], and Tropidocoryphe Novák, 1890, respectively (Budil 1995). The conodonts of the dark interval indicate Polygnathus ensensis Zone (Zikmundová \& Kalvoda in Galle \& Hladil 1991, Kalvoda 1992) but the Nowakia ex gr. otomari and other dacryoconarids observed in the UDI are less valuable for the correlation with the Kačák Member (Berkyová 2004). The dark interval is followed by bioclastic breccia (Bed 46; Hladil 1993) with tabulatomorphs and stromatoporoids dominated by Caliapora ex gr. battersbyi. This species is typical for the Eifelian-Givetian transitional interval (Hladil 1993). Siltstones and shales above the breccia were by Hladil et al. $(1991,1992)$ tentatively referred to the Roblín Member of the Srbsko Formation.

\section{Material and methods}

Twenty-six bulk samples (Figs 1,2) were treated with $15 \%$ acetic-acid solution. Their weights vary from 5 to 25 kilograms. After the dissolution of calcium carbonate the residues were washed by water, dried, and all phosphatic fossils were hand-picked from Petri dishes. The residues were not sieved to avoid the secondary fragmentation. Selected specimens were photographed using a Scanning Electron Microscope (SEM JEOL 6300) at the Biology Centre of the Academy of Sciences of the Czech Republic in České Budějovice. Some uncoated specimens were photographed with a digital microscope DINO-LITE.

The samples were poor or even barren on organophosphatic brachiopods. The quality of preservation of phosphatic shells depends on the original shell size. The shells of microbrachiopods (size below $1 \mathrm{~mm}$ ) exampled by Opsiconidion and Opatrilkiella are favourably preserved although even these small shells sometimes are deformed, folded or compressed. The preservation of larger shells is even worse. These shells with original size exceeding ca. $3 \mathrm{~mm}$ are represented only by small and folded fragments. This high rate of fragmentation is not artefact of the sampling method. This implies that the breakage of the shells originate already before the fossilization process. Despite their poor mode of preservation, the different ornaments of these fragments indicate presence of more species. Some of these small fragments are briefly described and illustrated, because they indicate moderate diversity in lingulates in the original ecosystem.

The conodonts dominate among the phosphatic fossils in all samples. Their moderate diversity with dominance of Polygnathus enables the exact biostratigraphical setting of the brachiopod fauna (Fig. 2). Apart of conodonts and phosphatic brachiopods, the samples yielded bones, scales and teeth of diverse gnathostomes (acanthodians, placoderms, sarcopterigians), conulariid fragments, byronid tubes and their fix discs, sclerites of Eurytholia, small fragments of phyllocarid crustaceans and phosphatic microspherules.

\section{Abbreviation used. - UDI: Upper dark interval.}

Repository. - All specimens, including the types, are housed in the palaeontological collections of the Centre of Biology, Earth and Environmental Sciences in the Faculty of Education of the University of West Bohemia in Plzen (PCZCU), Czech Republic.

\section{Systematic palaeontology}

Order Lingulida Waagen, 1885

Superfamily Linguloidea Menke, 1828

Remarks. - At least three species of the linguloideans are present in the UDI (Fig. 2). Apart of the new species of Lingulipora Girty, 1898, all other species are preserved as extremely tiny fragment. 
The first distinguished species likely belongs to moderate sized lingulid with flattened shell and distinct dorsal pseudointerarea with striated broad median groove. Its postlarval shell is almost smooth, lacking any distinct microornament (Fig. 5S, T). The second species is represented by thin shell covered by fine low regular concentric lines numbering $15-20$ per $1 \mathrm{~mm}$. This distinct ornament is slightly similar to microornament of Silurian glosseline Barrandeoglossa Mergl, 2001a (pl. 7, figs 12, 13). The third species is tiny and thin-walled, similarly sized and ornamented to Prastavia Mergl, 2001a. It bears fine concentric smooth growth bands and lacks any microornament. The last two species are not illustrated due extremely small size of fragments.

Family Lingulidae Menke, 1828

\section{Genus Lingulipora Girty, 1898}

Type species. - Lingula (Lingulipora) williamsiana Girty, 1898; Chattanooga Shale; Upper Devonian; Virginia, U.S.A.

\section{Lingulipora budili sp. nov.}

Figures 3, 4

Holotype. - Dorsal valve figured in Fig. 3A, B (PCZCU 2195).

Type horizon and locality. - Srbsko Formation, UDI, bed 45L (after Hladil et al. 1991) (Nowakia otomari Zone, Polygnathus ensensis Zone). North-eastern wall of the Jirásek’s Quarry, Koněprusy, Central Bohemia.

Material. - Four almost complete dorsal valves, one complete ventral valve and six fragments of dorsal and ventral valves (figured PCZCU 2195, PCZCU 2198-2203).

Etymology. - After Petr Budil, Czech Geological Survey, Prague, for his contribution to palaeontology of the Barrandian area.

Diagnosis. - Small thin-shelled Lingulipora with elongately elliptical shell outline, distinct ventral pseudointerarea, with sparse evenly spaced pores, lacking coarse radial ornament.

Description. - Shell minute, thin-walled, $1.3 \mathrm{~mm}$ long in largest entire shell (fragments indicate the larger shell size, with length $c a .3-4 \mathrm{~mm}$ ).

The dorsal valve is elongate elliptical, $c a .45 \%$ as wide as long, with evenly rounded anterior and posterior margins and weakly and regularly rounded sides. The valve is moderate convex in transverse profile. The valve
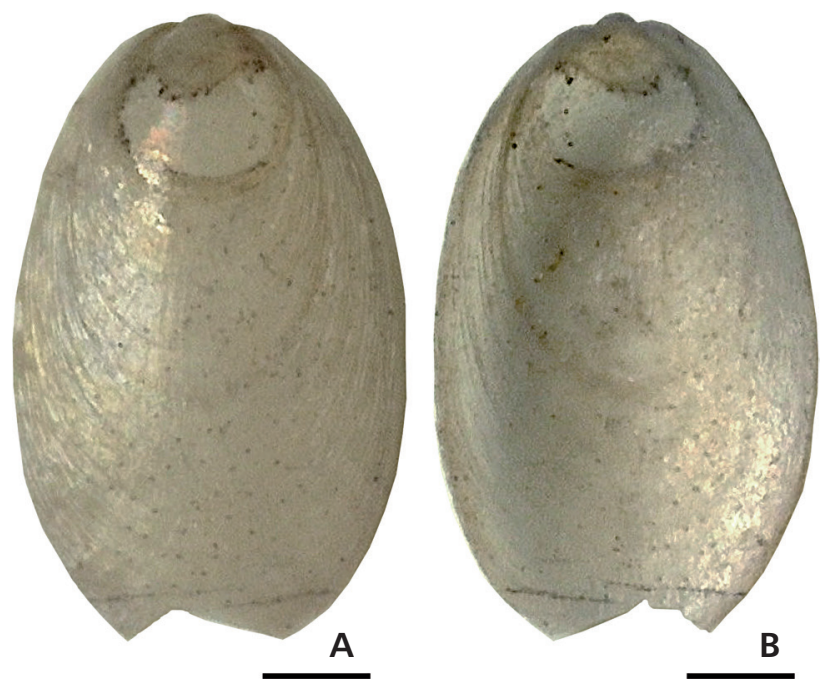

Figure 3. Lingulipora budili sp. nov., Srbsko Formation; Koněprusy, Jirásek's Quarry, UDI, TM/14; A, B - dorsal valve, exterior and interior, PCZCU 2195. $\operatorname{Bar}=200 \mu \mathrm{m}$.

is weakly arched in axial profile, with catacline slope posterior to the larval shell (Fig. 4B). There is none clearly defined dorsal pseudointerarea. The posterior shell margin is gently swollen into a narrow rounded edge, which laterally continues to somewhat broader and slightly flattened brim. The dorsal larval shell is subcircular, dome-shaped, $95 \mu \mathrm{m}$ wide, highly raised above adjacent surface of the postlarval shell. Surface of the larval shell bears 4 to 5 fine radial ribs on each side and fine shallow pits clustered on its posterodorsal surface.

The ventral valve shows the same outline and convexity as the dorsal valve but has posteriorly pointed straight beak. The ventral pseudointerarea is elevated above the valve floor having deep, short, broadly triangular, and anteriorly emarginated pedicle groove. Orthocline propareas lack the flexure lines and bear uneven growth lines which continue onto the floor of pedicle groove (Fig. 4F). The ventral larval shell distinctly overhangs the ventral pseudointerarea.

The shell interior lacks definite muscle impressions. The posterior floor of the dorsal valve shows finely pitted surface by epithelial cells moulds and unpaired larger pit placed below the larval shell, which could be an attachment site of umbonal muscles.

The ornament consists of fine concentric wrinkles distinct on flanks where fade towards the valve midsector. The radial ornament is formed by irregularly meandering fine wrinkles aligned along fine radial striations. The radial ornament entirely overprints the concentric ornament in the shell midsector (Fig. 4J). The shell is distinctly punctate, with pores evenly spaced over the shell exterior. The pores are clearly visible inside the translucent shell in uncoated specimens (Fig. 3). The internal opening of the 
pores are evenly scattered on the valve floors. The pores are uniformly sized, with funnel-like internal opening of $10 \mu \mathrm{m}$ in diameter. The diameter of pores is several times greater inside in shell interior than on the shell surface. The external pores are only ca. $2 \mu \mathrm{m}$ in diameter, having the elliptical outline with elongation axis tracing concentric lines. Each external opening is surrounded by shallow funnel-like depression.

Remarks. - Material is scanty and mostly fragmental but presence of fine canals making holes in the shell wall and features of the both pseudointerareas are near to those on shells referred to Lingulipora Girty, 1898 by Baliński $(1988,1997)$. The similarities deal of microornamentation, morphology of pores (Baliński 1988), and the larval development (Baliński 1997, 2001). The dorsal larval shell of Lingulipora sp. (Baliński 1997, fig. 2f) is nearly identical with the larval shell of new species. The gross morphology of the Bohemian specimens is similar to specimens coming from the Frasnian of Debnik in Southern Poland (Baliński 1979). Baliński (1988) suggested that Lingulipora is represented by several unnamed species in the Frasnian and lower Famennian of the Holy Cross Mountains and the Cracow region. He widely discussed variations in radial microornament of their mostly fragmentary shells but did not erect any formal name for these specimens.

The type species Lingulipora williamsiana Girty, 1898 is poorly known species known from Chattanooga Shale (Famennian) of Appalachian Mountain region, but it is much larger and has the parallel-sided flanks. Lingulipora porifera Cooper \& Dutro, 1982 from the base of the Percha Shale of New Mexico (Famennian) differs from the new species by the parallel sided subcarinate shell and the larger shell size.

Occurrence. - The type locality only (Fig. 2), rare. The earliest occurrence (one fragment) comes from thin bed of grey crinoidal limestone of the Acanthopyge Limestone (Tortodus kockelianus Zone), Koněprusy, Jirásek's Quarry, samples JI/95, JI/96; the commonest occurrence is in UDI (Polygnathus ensensis Zone) at same locality, samples $\mathrm{TM} / 12, \mathrm{TM} / 14$.

Family Paterulidae Cooper, 1956

\section{Genus Paterula Barrande, 1879}

Type species. - Paterula bohemica Barrande, 1879; Vinice Formation; Sandbian, Ordovician; Barrandian, Czech Republic.

Paterula holynensis Mergl, 2001a

Figure 5A-G 2001a Paterula holynensis sp. n.; Mergl, p. 18, pl. 11, figs 9-13, pl. 12, figs 1-15.

2012 Paterula holynensis Mergl, 2001a. - Mergl \& Vodrážková, p. 319 , fig. $7 \mathrm{~g}, \mathrm{k}$.

Material. - One ventral valve (PCZCU 2205) and two fragments.

Remarks. - The sampled shells are morphologically undistinguishable from the topotypic specimens of $P$. holynensis coming from the base of the Choteč Formation in the Prastav Quarry, Praha-Holyně. The characteristic ridge on the posterior slope of the ventral valve (Mergl 2001a, pl. 12 , figs 14,15 ) is somewhat weaker in the specimen from the Jirásek's Quarry (Fig. 5C) but this is likely due to the larger size of topotypic specimens. The microornament of entire shell from the UDI is identical, with the broadly rhombic flat-bottomed pits at the larval shell changing to the narrowly rhombic pits arranged in radial strips in later growth stages (Fig. 5F, G).

Occurrence. - Eifelian, Třebotov Limestone (Polygnathus partitus Zone), locality: Choteč, Na Škrábku Quarry (Mergl \& Vodrážková 2012). Eifelian, Choteč Formation, lower part (Polygnathus costatus Zone), localities: Holyně, Prastav Quarry; Choteč, Na Škrábku Quarry; Karlštejn, U Němců section (Mergl 2001a, Mergl \& Vodrážková 2012). Eifelian, Choteč Formation, middle part, locality: Choteč, Na Škrábku Quarry (one specimen, new). Eifelian-Givetian boundary interval, Srbsko Formation, UDI (Nowakia otomari Zone, Polygnathus ensensis Zone), locality: Koněprusy, Jirásek's Quarry, sample $\mathrm{TM} / 12$.

Superfamily Discinoidea Gray, 1840

Family Discinidae Gray, 1840

\section{Genus Orbiculoidea d'Orbigny, 1847}

Type species. - Orbicula forbesii Davidson, 1848; Wenlock, Silurian; West Midlands, England.

\section{Orbiculoidea sp.}

Figure 5Q, R

Material. - Eight fragments (figured PCZCU 2210).

Description. - The shell is moderate to large sized, thinwalled, subcircular to elongate oval, having probably convexo-plane profile as can be reconstructed from available fragments. Ventral rugellae are lamellose, high or low ridge-like to low and filose depending in their location on shell. The high lamellose rugellae are distinctly inclined toward the apex, with the base resting almost orthogonally 


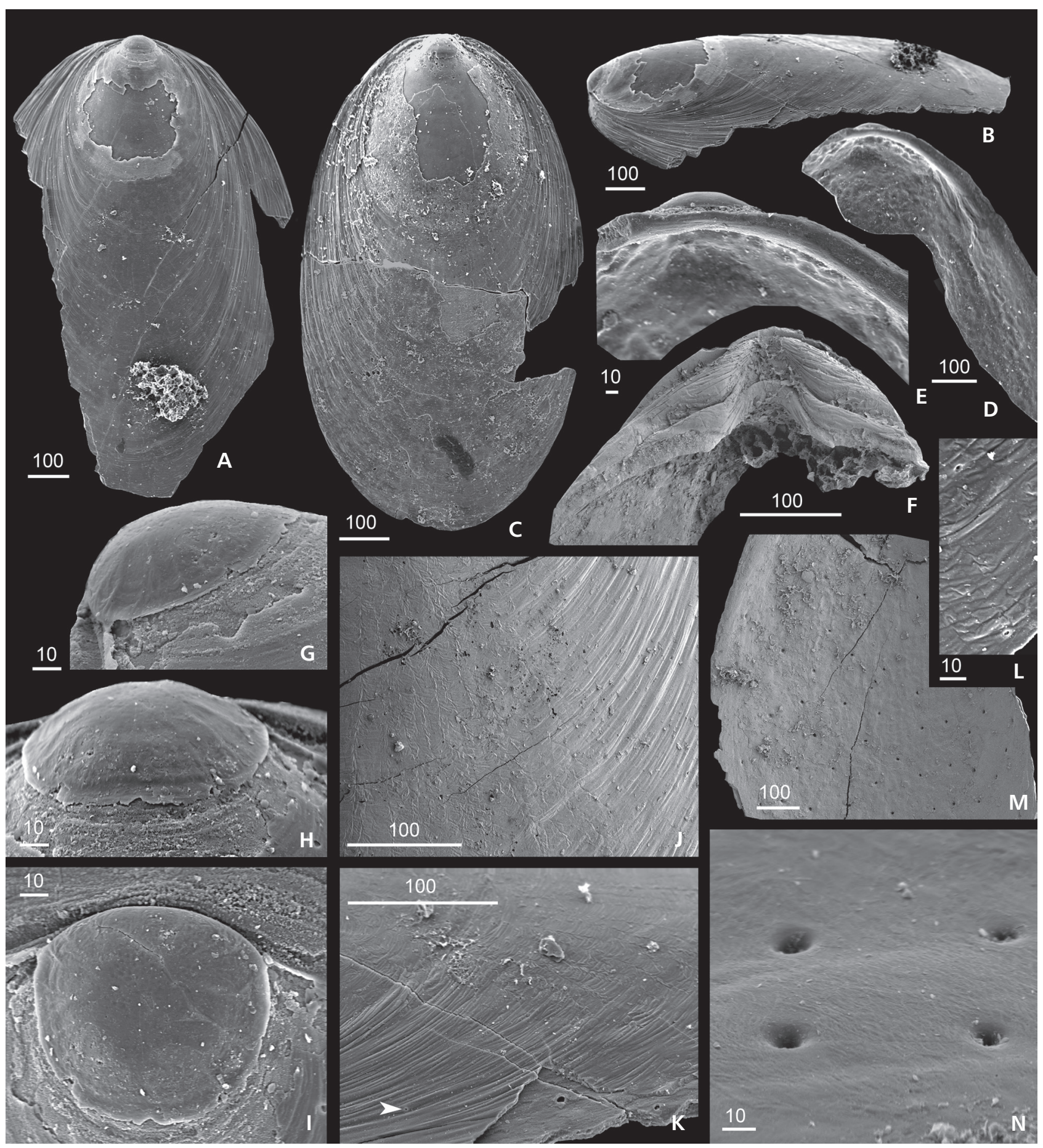

Figure 4. Lingulipora budili sp. nov., Srbsko Formation; Koněprusy, Jirásek’s Quarry, UDI, sample TM/12; A, B, G-I, K, L - dorsal valve, exterior of incomplete valve in dorsal (A) and laterodorsal (B) views, the larval shell in side (G), anterior (H) and dorsal (I) views, the pore in inner shell layer (K), and the external pore (marked by white arrow) in the primary shell (L), PCZCU 2198; C - dorsal valve, exterior, PCZCU 2199; E, D - incomplete dorsal valve, interior (D) and detail of the interarea (E), PCZCU 2200; F, M - incomplete ventral valve, detail of the pseudointerarea (F) and the valve floor showing regular spacing of pores (M), PCZCU 2201; J - fragment of the valve showing concentric growth wrinkles and radial ornament, PCZCU 2202; N - opening of pores on valve floor in oblique view (N), PCZCU 2203. Bars in $\mu \mathrm{m}$.

onto shell. Interspaces are broad having flat bottom. Interspaces and sides of rugellae are entirely covered by fine concentric fila. Radially arranged rays of vesicular pits are distinct in some fragments but absent in others. This is likely original difference indicating the uneven production of vesicles in particular sectors of the shell. 
The ventral valve posterior margin is entire. The pedicle opening is small, with small spindle-shaped listrium.

Remarks. - The shell is distinct by planar or subplanar ventral valve and thin lamellose rugellae, having the similar ornament to Recent Discinisca lamellosa (Broderip, 1833). Equally shaped discinoid brachiopod is unknown in the Acanthopyge Limestone (Mergl 2008).

Occurrence. - Eifelian-Givetian boundary interval, Srbsko Formation, UDI (Nowakia otomari Zone, Polygnathus ensensis Zone), locality: Koněprusy, Jirásek’s Quarry, samples TM/1, TM/4, TM/6, TM/7, TM/12.

\section{Genus Acrosaccus Willard, 1928}

Type species. - Acrosaccus shuleri Willard, 1928; Caradoc, Ordovician; Virginia, U.S.A.

\section{Acrosaccus sp.}

Figure 5O, $\mathrm{P}$

Material. - Five fragments (figured PCZCU 2208, 2209).

Description. - The shell is thick walled, moderately to large sized judging from thick-walled fragments. The ventral valve is low-conical at least in the early growth stage. The dorsal valve is low conical or almost planar, with submarginal apex. Ventral opening is covered by a small narrowly triangular listrium. The ornament consists of concentric rugellae of uneven size, separated by narrower concave interspaces. Microornament consists of fine densely arranged vesicular pits of subcircular outline.

Remarks. - The similarly shaped and thick-walled discinoid brachiopod is unknown from the Acanthopyge Limestone (Mergl 2008). The fragments can hardly be referred to Orbiculoidea tarda (Barrande, 1879), which is common species in the Srbsko Formation (Mergl 2001a). The main difference is a coarsely rugellate ornament and thick-walled shell of specimens from the UDI.

Occurrence. - Eifelian-Givetian boundary interval, Srbsko Formation, UDI (Nowakia otomari Zone, Polyg- nathus ensensis Zone), locality: Koněprusy, Jirásek's Quarry, samples TM/1, TM/6, TM/10, TM/12.

\section{Genus Chynithele Havlíček, 1996 in Havlíček \& Vaněk (1996)}

Type species. - Chynithele ventricona Havlíček 1996; Zlíchov Formation; Emsian, Devonian; Barrandian, Czech Republic.

\section{Chynithele amoena Mergl, 2008}

2008 Chynithele amoena sp. n.; Mergl, pp. 289, 290, fig. 7.

2012 Chynithele amoena Mergl, 2008. - Mergl \& Vodrážková, p. 320, fig. 7e.

Remarks. - Fragments of the dorsal valve with characteristically curved crests of rugellae have been observed in the upper part of Acanthopyge Limestone (samples $\mathrm{JI} / 93, \mathrm{JI} / 100$ ). None similar fragment of this species was observed in UDI samples. Fragments are referred with some uncertainty to Chynithele amoena Mergl, 2008 which is the common species in the Acanthopyge Limestone.

Occurrence. - Emsian, Třebotov Limestone (Polygnathus serotinus Zone), locality: Choteč, Na Škrábku Quarry (Mergl \& Vodrážková 2012). Eifelian, Acanthopyge Limestone (Polygnathus costatus Zone), locality: Koněprusy, Preisler's Quarry, samples AC1, AC2 (Mergl 2008). Eifelian, Acanthopyge Limestone (Tortodus kockelianus Zone), locality: Koněprusy, Jirásek's Quarry, samples JI/93, JI/100.

\section{Genus Opatrilkiella Mergl, 2001a}

Type species. - Opatrilkiella minuta Mergl, 2001a; Požáry Formation; Př́idolí, Silurian; Barrandian, Czech Republic.

\section{Opatrilkiella kobyla Mergl, 2008}

Figure 6

2001a Opatrilkiella (?) sp. B. - Mergl, p. 30, pl. 24, fig. 10. 2008 Opatrilkiella kobyla sp. nov.; Mergl, p. 290, figs 8, 9.

Figure 5. A-G - ventral valve of Paterula holynensis Mergl, 2001a, Srbsko Formation, Koněprusy, Jirásek’s Quarry, UDI, TM/12; ventral valve in ventral (A) and lateroventral (B) views, detail of posterior part of valve (C), ventral larval shell on ventral (D) and oblique (E) views, detail of microornament (F), and rhombic pits of microornament (G), PCZCU 2205. • H-N - Orbaspina sp., Srbsko Formation, Koněprusy, Jirásek’s Quarry, UDI, samples TM/03 (I, J), TM/12 (H, K-N); H, L - fragment of valve with two growth lamellae (H) having aligned hollow spines (L), PCZCU 2206; I, J - ventral valve, exterior (I) and interior (J) of plate covering pedicle track, PCZCU 2197; K, M, N - fragment of valve in external (K) and oblique (M) views, and detail of spinose ornament (N), PCZCU 2207. • O, P - Acrosaccus sp., Srbsko Formation; Koněprusy, Jirásek's Quarry, UDI, sample TM/12; O - fragment of valve, PCZCU 2209; P - fragment of valve, PCZCU 2208. • Q-R - Orbiculoidea sp., Srbsko Formation; Koněprusy, Jirásek’s Quarry, UDI, sample TM/12; fragment of valve, PCZCU 2210. • ?Obolidae gen. et sp. indet., Srbsko Formation; Koněprusy, Jirásek’s Quarry, UDI, sample TM/12; S, T - fragment of valve, PCZCU 2204. Bars in $\mu \mathrm{m}$. 


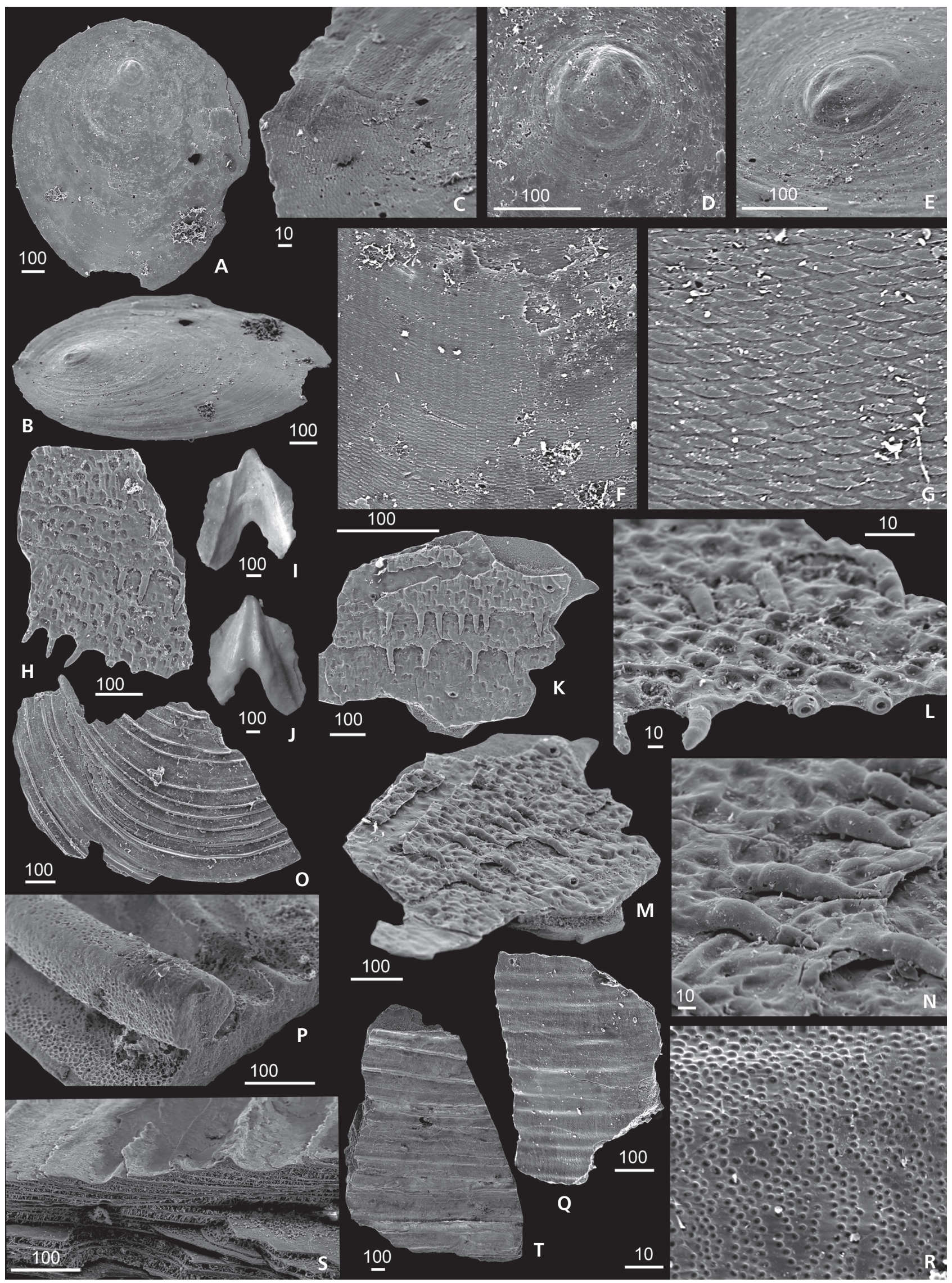




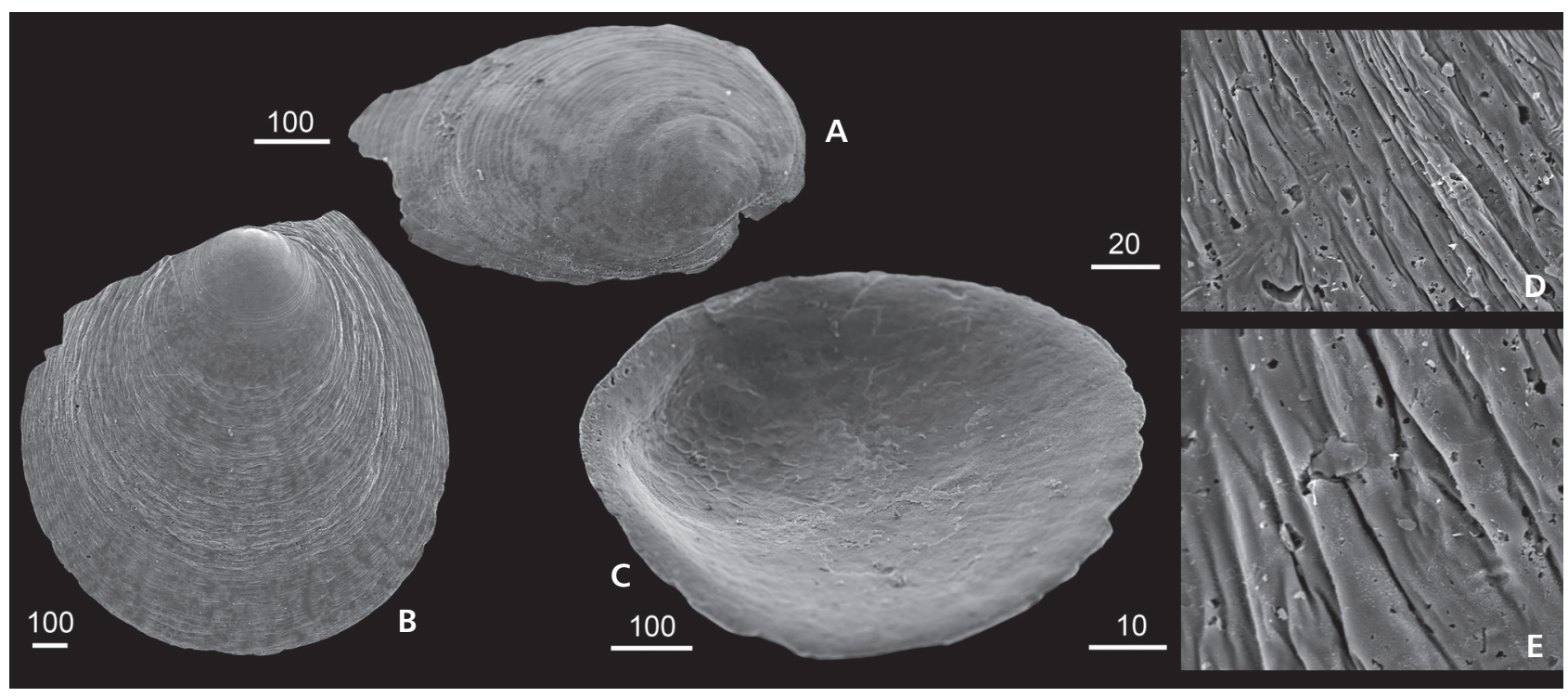

Figure 6. Opatrilkiella kobyla Merg1, 2008, Srbsko Formation; Koněprusy, Jirásek’s Quarry, UDI, sample TM/12 (A); Choteč Formation, Acanthopyge Limestone, sample JI/94 (B-E); A - ventral valve in posterolateral view, PCZCU 2224; B, D, E - dorsal valve exterior and details of its ornament, PCZCU 2211; C - dorsal valve interior in oblique view, PCZCU 2212. Bars in $\mu \mathrm{m}$.

2009 Opatrilkiella kobyla Merg1, 2008. - Mergl \& Ferrová, p. 532, figs 8,9 .

2012 Opatrilkiella kobyla Merg1, 2008. - Merg1 \& Vodrážková, p. 322, fig. 7j, 1.

2015 Opatrilkiella kobyla Mergl, 2008. - Mergl \& JiménezSánchez, p. 183, fig. 5c, e, f, h-j.

Material. - Five shells (figured PCZCU 2211, 2212, 2224).

Description. - The shell is about $2 \mathrm{~mm}$ long in maximum, thin-walled, broadly transverse oval in the early growth stage becoming more elongate with next growth. Sides are evenly rounded. The shell is weakly convex in transverse and axial profiles. The apex is situated near the posterior margin, with the first growth halo in $150 \mu \mathrm{m}$ wide shell. Ornament consists from densely spaced growth fila forming drape-like folds at the median sector of the valve. Radially arranged and regularly widening flat rays become distinct from the early growth stages.

The ventral valve has the same outline and convexity, with the apex located above the posterior margin at the tip of low widely triangular catacline pseudointerarea. The narrowly triangular pedicle slit is bordered by broad and low triangular propareas.

Remarks. - All known species of the genus Opatrilkiella Mergl, 2001a broadly vary in their shape having broadly elongate oval, subtriangular to roundly subrectangular outline (Mergl 2001a, Mergl \& Ferrová 2009, Merg1 \& Vodrážková 2012). The width is accentuated in the specimens from the Jirásek's Quarry, but there is suggestion that this falls within range of phenotypic plasticity of the species. Shells from Jirásek's Quarry show very low ventral pseudointerarea. Pseudointerareas of O. minuta Mergl, 2001a (Př́dolí, Požáry Formation) and O. kobyla Mergl, 2008a are higher and narrower than in specimens now described. The very low ventral pseudointerarea of $O$. kobyla from the UDI makes its shell similar to the ventral valve of Schizobolus Ulrich, 1886, well-illustrated firstly by Baliński \& Holmer (1999, fig. 4) and subsequently by Morzadec et al. (2015, fig. 5i). However, apart from distinctly larger adult shell size, the elevated growth fila of Schizobolus are different from the waved growth fila of Opatrilkiella.

Occurrence. - Eifelian, Choteč Formation, lower part (Polygnathus partitus to P. costatus zones), localities: Choteč, Na Škrábku Quarry; Chýnice (Jirásek mill); PrahaHolyně, Prastav Quarry; Praha-Barrandov (road cut). Eifelian, Acanthopyge Limestone (Tortodus kockelianus Zone), locality: Koněprusy, Jirásek's Quarry, samples JI/94, JI/96. Eifelian-Givetian boundary interval, Srbsko Formation, UDI (Nowakia otomari Zone, Polygnathus ensensis Zone), locality: Koněprusy, Jirásek’s Quarry, samples TM/5, TM/12, TM/14.

Order Acrotretida Kuhn, 1949

Superfamily Acrotretoidea Schuchert, 1893

Family Biernatidae Holmer, 1989

Remarks. - Grow observations on the morphology of the Silurian and Devonian biernatids indicate that the morphological difference and corresponding taxonomic diversity inside this clade are higher that suggested a few 


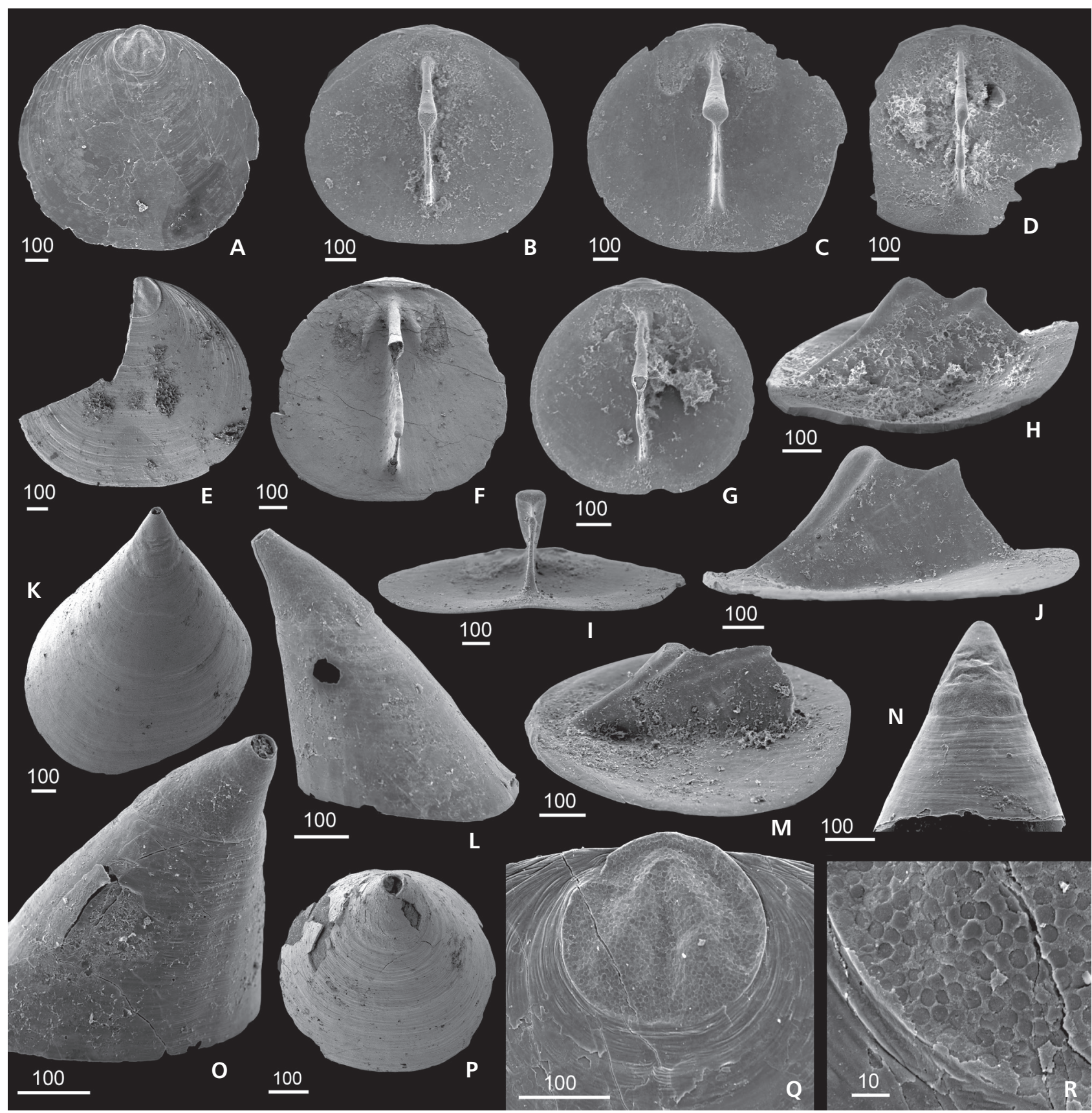

Figure 7. Opsiconidion decessus Mergl, 2001a, Srbsko Formation; Koněprusy, Jirásek’s Quarry, UDI, sample TM/12; A, Q, R - dorsal valve exterior, PCZCU 2213; B, M - dorsal valve interior, PCZCU 2214; C, I, J - dorsal valve interior, PCZCU 2215; D, H - dorsal valve interior, PCZCU 2216; E - dorsal valve exterior, PCZCU 2217; F - dorsal valve interior, PCZCU 2218; G - dorsal valve interior, PCZCU 2219; K - ventral valve, oblique view PCZCU 2220; L, O - ventral valve, side (L) and posterolateral (O) views, PCZCU 2221; N - ventral valve, anterior view, PCZCU 2222; $\mathrm{P}$ - ventral valve, apical view, PCZCU 2223. Bars in $\mu \mathrm{m}$.

years ago (Brock et al. 1995; Mergl 2001a, 2008; Mergl \& Ferrová 2009; Mergl \& Vodrážková 2012; Mergl \& Jiménez-Sánchez 2015). However, the differences between particular species are less conspicuous than in other clades of the Acrotretacea. The significance of phenotypic plasticity of Opsiconidion is also less understood, but the recent survey (Mergl et al. 2018) observed that even minute features are remarkably stable in particular assemblages and the phenotypic plasticity should not be overestimated. Unlike to other stratigraphical intervals in the Bohemian Devonian, three fairly disparate biernatid species appear in the late Eifelian strata. However, similar to finds of biernatids elsewhere, only the dorsal valves are known sufficiently in two of three present species at the 
summit of the Acanthopyge Limestone sequence and the UDI at the Jirásek's Quarry.

\section{Genus Opsiconidion Ludvigsen, 1974}

Type species. - Opsiconidion arcticon Ludvigsen, 1974; Emsian, Devonian; Yukon, Canada.

\section{Opsiconidion decessus Mergl, 2001a}

Figure 7

2001a Opsiconidion decessus sp. nov.; Mergl, p. 34, pl. 31, figs 4-16.

2008 Opsiconidion decessus Mergl, 2001a. - Mergl, p. 294, fig. 10.

2012 Opsiconidion decessus Mergl, 2001a. - Mergl \& Vodrážková, p. 324, fig. 9a-n.

Material. - 58 dorsal and 32 ventral valves (figured PCZCU 2213-2223).

Remarks. - Morphology and stratigraphic extension of the species was discussed by Mergl (2008) and Mergl \& Vodrážková (2012). The species is known from upper Emsian (Třebotov Limestone, serotinus Zone) to upper Eifelian (Acanthopyge Limestone). New observations indicate its presence also in the Polygnathus ensensis Zone. Mergl (2008) stressed its rarity in samples AC1 and AC3, which likely came from upper part of the Polygnathus costatus Zone. The species is the commonest brachiopods in the UDI and confirms the previous observations that the Opsiconidion species are most abundant in dark limestone of suggested deeper water origin. This mode of occurrence favoured the epiplanktonic mode of life assumed by Mergl \& Vodrážková (2012).

Occurrence. - Eifelian, Choteč Formation, Třebotov and Choteč limestones, lower part (Polygnathus partitus to T. kockelianus zones), localities: Choteč, Na Škrábku Quarry; Chýnice (Jirásek mill); Praha-Holyně, Prastav Quarry; Praha-Barrandov (road cut) (Mergl 2008, Mergl \& Vodrážková 2012). Eifelian, Acanthopyge Limestone (Tortodus kockelianus Zone), locality: Koněprusy, Jirásek's Quarry, samples JI/95, JI/96, JI/100. Eifelian-Givetian boundary interval, Srbsko Formation, UDI (Nowakia otomari Zone, Polygnathus ensensis Zone), locality: Koněprusy, Jirásek's Quarry, samples TM/5, TM/6, TM/8, $\mathrm{TM} / 10, \mathrm{TM} / 12, \mathrm{TM} / 14$.

\section{Opsiconidion nanus sp. nov.}

Figure 8G-O

Holotype. - PCZCU 2232, the dorsal valve figured in Fig. $8 \mathrm{~K}-\mathrm{M}$.
Type horizon and locality. - Eifelian, Acanthopyge Limestone, upper part, sample JI/96. Czech Republic, Koněprusy, Jirásek’s Quarry.

Material. - Seven dorsal valves and one fragment of ventral valve (figured PCZCU 2228-2233).

Etymology. - Nanus (Latin), referring to the small shell size.

Diagnosis. - Small and relatively thick-shelled Opsiconidion with trapezoidal outline of dorsal valve.

Description. - The shell is thick-walled relative to its size, in maximum $500 \mu \mathrm{m}$ wide, as wide as long. The anterior commissure is weakly unisulcate.

The dorsal valve is trapezoidal in outline, widest at the anterior one-third, with straight anterior margin, evenly rounded flanks and weakly curved posterolateral margins. The larval shell distinctly overhangs a straight posterior margin. The valve is almost flat having very broad shallow sulcus along its axial part and poorly convex flanks. The dorsal pseudointerarea is low, moderate anacline, occupying about $30 \%$ of the valve width. The median groove is flat and weakly defined. Propareas are very narrow and also poorly defined.

The dorsal valve interior has prominent median septum. It starts at the umbonal chamber and extends anteriorly to almost $70-80 \%$ of the valve. The septum is almost $50 \%$ as high as long, with a blade-like base. Its whole crest bears a robust, anteriorly widening upper rod having flattened to shallowly grooved posteroventral surface. The lower rod is much delicate, short and extends much anteriorly than the upper rod. Both rods have blunt anterior ends. The upper rod ends at the mid-length of the valve and lower rod at $60-70 \%$ of the valve. The visceral area is clearly defined and occupies $50 \%$ of the valve length and $60-70 \%$ of the valve width. It surface is distinct by deeply imprinted epithelian cell moulds. Three pairs of muscle scars are visible. The cardinal muscle scars are large, elongate oval, with rounded outer border and straight inner border. The much smaller triangular anterocentral scars are located at the centre of the valve, in a narrow band between anterior corners of cardinal muscle scars and the median septum. Small short and transverse umbonal muscle scars adjoin to sides of median septum base. The valve floor outside the visceral area bears fine radially disposed rays that likely corresponds to distal vascular canals. The proximal parts of vascula media and vascula lateralia are not discernible. The valve floor around shell periphery forms a narrow flattened brim.

The exterior of the dorsal valve has clearly defined larval shell. It is circular, $150 \mu \mathrm{m}$ sized, extended backward over the posterior margin of the valve. Two distinct nodes are present. Margin of the larval shell is clearly 


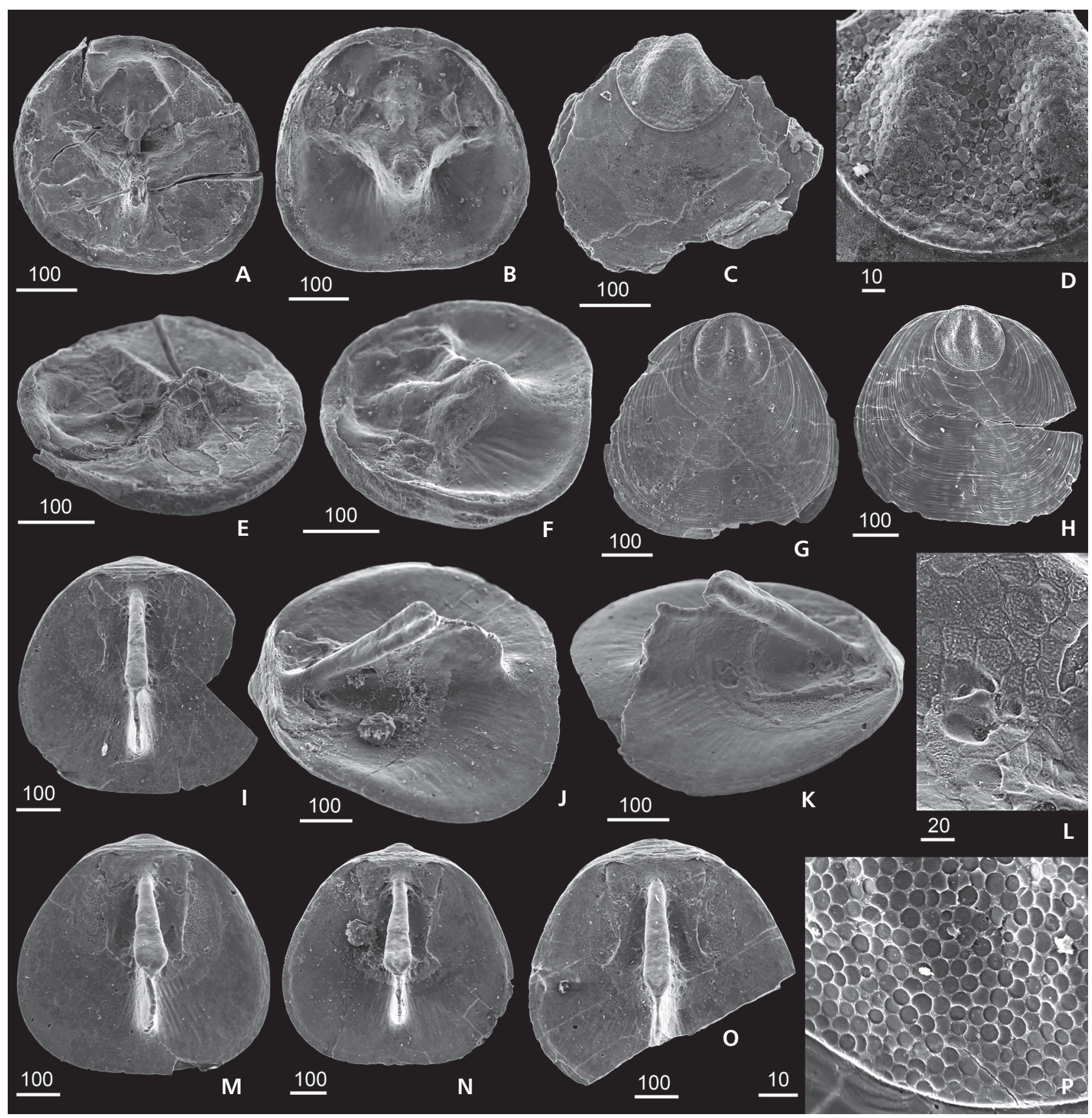

Figure 8. A-F - Biernatidae gen. et sp. indet., Choteč Formation, Acanthopyge Limestone, sample JI/100; A, E - dorsal valve interior, PCZCU 2225; B, F - dorsal valve interior, PCZCU 2226; C, D - dorsal valve exterior and detail of larval shell, PCZCU 2227. • G-P - Opsiconidion nanus sp. nov., Choteč Formation, Acanthopyge Limestone, sample JI/96; G - dorsal valve exterior, PCZCU 2228; H, P - dorsal valve exterior and detail of larval shell, PCZCU 2229; I - dorsal valve interior, PCZCU 2230; J, N - dorsal valve interior in oblique and internal view, PCZCU 2231; K, L, M - dorsal valve interior in oblique $(\mathrm{K})$ an internal $(\mathrm{M})$ views, and detail of epithelial cell moulds (L), PCZCU 2232; O - dorsal valve interior, PCZCU 2233. Bars in $\mu \mathrm{m}$.

defined by raised edge above the post-larval shell surface. The larval shell bears the pits of two sizes. The larger circular pits are flat-bottomed, almost uniformly 4.0-4.5 $\mu \mathrm{m}$ sized (extremes 3-5 $\mu \mathrm{m}$ ), occasionally overlapping each another over a short distance (generally less than one-third its diameter). The interspaces between the large pits are densely covered by smaller, less than $0.5 \mu \mathrm{m}$ sized pits. The postlarval shell is covered by entire concentric growth fila of uniform size with exception of the shallow sulcus where irregular folds and drapes are present.

The ventral valve is narrowly acutely conical, but poorly known due very fragmental state of preservation. 
Remarks. - When first seen the individuals of the $O$. nanus sp. nov., the shells look as juvenile shells of any other species of Opsiconidion. However, the shells of $O$. nanus are thick-walled relative to their size, with heavily mineralized internal shell structures, marked by deeply imprinted muscle scars and clearly seen epithelial cell moulds. The shell outline of $O$. nanus is invariably trapezoidal. The associated biernatiid determined herein as Opsiconidion decessus Mergl, 2001 a has the almost circular shell outline, the thinner shell wall relative to shell size, and shorter and poorly defined visceral area having weak muscle imprints with much shorter cardinal muscle scars. The dorsal pseudointerarea of $O$. nanus is moderate anacline and large relative to shell size while the dorsal pseudointerarea of associated $O$. decessus is comparatively smaller. Apart of these differences, the diminutive size distinguishes the new species from all previously described species.

Occurrence. - Eifelian, Acanthopyge Limestone (Tortodus kockelianus Zone), locality: Koněprusy, Jirásek’s Quarry, samples JI/94, JI/96.

\section{Biernatidae gen. et sp. indet. Figure $8 \mathrm{~A}-\mathrm{F}$}

Material. - Three dorsal valves (PCZCU 2225-2227).

Description. - The shell is small, in maximum $400 \mu \mathrm{m}$ wide, as wide as long, very thick-walled relative to its size, with imperfect bilateral symmetry. The dorsal valve is subcircular to subquadrate, widest anterior to the midlength, with rounded posterior margin and sides, and less rounded anterior margin. Distinct flattened brim encircles almost whole shell except of small orthocline pseudointerarea. The valve is weakly convex in the transverse and longitudinal profiles, with shortly geniculate sides.

The dorsal valve interior is marked by extremely thick visceral area extending anterior to the shell midlength. The median septum has shape of thick high mound-like elevation near the centre of the valve. The posterior base of the septum has a form of low and wide elevated ridge. Anterior part of the median septum is supported by thick short ridge. There is no structure similar to surmounting plate. Cardinal muscle scars are large, extending to almost shell midlength, deeply inserted into shell posteriorly and elevated above shell floor anteriorly. The anterocentral muscle scars rest on very thick platform united with the median septum. Remaining parts of the visceral area are deeply impressed into posterior part of the valve floor. The anterior part of the valve floor is distinct by radially arranged shallow imprints of vascular canals.

The larval shell is circular, with two diverging elevated nodes. Its surface bears shallow pits, generally intersecting one another, leaving almost no interspaces in between. Surface of the postlarval shell bears weak growth lines.

Remarks. - The species is represented only by tree dorsal valves, without any valuable data about the ventral valve, and therefore it is left in open taxonomic position. However, the interior of the dorsal valve is very unusual lacking gross similarity to any of already described ancestral or associated biernartid species. The absence of upper and lower rods, the extremely thick median septum, the highly elevated visceral area, and very thick shell are unique features. Exterior and shape of the larval shell indicate, that the shells are related to the Biernatidae. It seems improbable that shell represent only extremely gerontic specimen associated $O$. nanus sp. nov. or $O$. decessus Mergl 2008. Moderate asymmetry of the shell (Fig. $8 \mathrm{~B})$ is other unusual feature in biernatids.

Occurrence. - Eifelian, Acanthopyge Limestone (Tortodus kockelianus Zone), locality: Koněprusy, Jirásek’s Quarry, sample JI/100.

Superfamily Siphonotretoidea Kutorga, 1848

Family Siphonotretidae Kutorga, 1848

\section{Genus Orbaspina Valentine \& Brock, 2003}

Type species. - Orbaspina gelasinus Valentine \& Brock, 2003; Wenlock, Silurian; New South Wales, Australia.

\section{Orbaspina sp.}

Figure $5 \mathrm{H}-\mathrm{N}$

Material. - One minute fragment of the ventral valve and twelve shell fragments (figured PCZCU 2197, PCZCU 2206, 2207).

Description. - As can be observed from the fragments, the shell of this siphonotretid is thin-walled, likely up to $5 \mathrm{~mm}$ sized, having weakly convex surface with somewhat depressed posterolateral parts and evenly curved shell periphery. The ventral pedicle opening is posteriorly closed by narrowly triangular plate of two medially fused thickened shell pads (Fig. 5I, J).

Ornament consists of weakly developed concentric growth rings. The growth edges are marked to almost tangentially oriented, short, narrowly conical hollow spines. The wavy and evenly pitted surface on growth bands greatly originated from imprinting of generally unpreserved spines from the preceding growth bands. Some of spines are partially greatly embedded into newly formed shell growth band. The observed length of spines is about $50 \mu \mathrm{m}$, their maximum diameter at proximal part is nearly $20 \mu \mathrm{m}$. Details of the shell interior are unknown. 
Remarks. - Despite very fragmentary state of preservation which makes formal description of new species premature, the attribution of these fragments into the order Siphonotretida is unambiguous. The fragments bearing hollow spines and the plate closing the posterior part of the pedicle track (Fig. 5I, J) are diagnostic for the postOrdovician siphonotretid Orbaspina. Rare and generally insufficiently known siphonotretids in the Silurian and Lower Devonian of Central Europe (Mergl 2001a, b; Mergl \& Vodrážková 2012; Mergl \& Jiménez-Sánchez 2015) differ from specimens present in the UDI by slender and less numerous hollow spines. Larger holes penetrating the shell wall, which were observed in O. chlupaci Mergl, 2003 (Mergl et al. 2018) and O. gelasinus Valentine \& Brock, 2003 were not observed in specimens from UDI.

Occurrence. - Eifelian-Givetian boundary interval, Srbsko Formation, UDI (Nowakia otomari Zone, Polygnathus ensensis Zone), locality: Koněprusy, Jirásek’s Quarry, samples TM/3, TM/12, TM/14.

\section{Discussion}

Reports about evolutionary history of Emsian, Eifelian and Givetian organophosphatic brachiopods are poor; if any, these are focused to taxonomy or are strongly generalised (Boucot 1975). Outside the Barrandian of the Czech Republic, the data on spatial and time distributions of small-sized lingulates from the Emsian to the Givetian are rare (Ludvigsen 1974, Brock et al. 1995).

In the Barrandian area, the lingulate brachiopods from the Eifelian (Acanthopyge and Choteč limestones, Polygnathus costatus Zone) were described by Mergl (2008) and Mergl \& Vodrážková (2012). Newly described fauna from the Tortodus kockelianus Zone is numerically as well as taxonomically poorer than that described from older part of the Acanthopyge Limestone by Mergl (2008). Despite ubiquitous genera Opsiconidion and Opatrilkiella, and micromorphic discinid Chynithele, other genera are absent (Kosagittella Mergl, 2001a; Microbolus Mergl, 2008; Acrosaccus; Orbiculoidea) in upper part of the Acanthopyge Limestone. No doubt, this is connected with existence of shallow water, highenergy environment in the Koněprusy area. The UDI yielded different lingulate fauna. This interval may correspond to the Kačák Event or another very closely timed anoxic event (Hladil et al. 1991, Budil 1995). The ubiquist Opsiconidion is numerically dominant; the second ubiquist Opatrilkiella is rarer, associated with rare ecological generalists Orbiculoidea and Acrosaccus. However, other genera of the UDI are much more interesting.
The genus Paterula is long-ranging taxon. It appears in the Dapingian (Mergl 1999) and with little morphological change persisted to the early Eifelian (Polygnatus partitus Zone) (Mergl 2001a, Mergl \& Vodrážková 2012). Its presence in the UDI indicates prominent environmental change in the UDI in relation to the preceding Acanthopyge Limestones interval. Paterula is typical outer shelf taxon (Mergl 1999, Sutton et al. 2000). In the life, the Paterula animal firmly attached on surface of elevated substrates (Lenz 1993, Mergl 2002). Presence of Paterula in the UDI extends the range of the genus to latest Eifelian (Polygnathus ensensis Zone) and signalizes a deeper oxygen reduced environment during the UDI sedimentation.

The genus Lingulipora is known from the Givetian to the Pennsylvanian (Holmer \& Popov 2000), with maximum reports from the Frasnian and the Famennian (Girty 1898; Baliński 1979, 1988, 1995, 1997; Cooper \& Dutro 1982). It known geographic extension has been restricted to Laurussian palaeocontinent (Kentucky, Oklahoma, New Mexico, Virginia, Poland, Russia). Its common occurrence in the UDI indicates its moderate abundance already in the latest Eifelian (Polygnathus ensensis Zone). Its earliest stratigraphic report came from the Acanthopyge Limestone (Tortodus kockelianus Zone). The Laurussian origin of the genus is questionable, because its earliest occurrence is peri-Gondwanan. Its abundance in the UDI coincides with suggested hypoxy because also other occurrences of Lingulipora (e.g. Virginia, New Mexico) are in dark shale or limestone.

The genus Orbaspina is long-ranging minute siphonotretid, with its micromorphic ancestor known already in the Darriwilian (Mergl 2002, pl. 41, figs 15-17). There are few records of post-Ordovician siphonotretids (Mergl 2001a, b; Valentine \& Brock 2003; Mergl et al. 2018). The Devonian siphonotretids are extremely rare among microbrachiopod assemblages (Mergl 2001a, Mergl \& Vodrážková 2012, Mergl \& Jiménez-Sánchez 2015). These rare Devonian forms have size around $1 \mathrm{~mm}$. The fragments indicate that shell of Orbaspina sp. from the UDI was much larger. The rounded periphery of fragments indicates that the shell width reaches five or even more millimetres. This disagrees with the size of other described Devonian micromorphic siphonotretids. Larger size indicates favourable conditions for metabolism of Orbaspina sp., likely the moderately hypoxic environment. Abundance of Orbaspina sp. in the UDI indicates that siphonotretids not only overstepped the Lower-Middle Devonian boundary, but also had profit from environmental changes of the Kačák Event. Whether oxygen reduced environment, bacterial bloom or other factor(s) were responsible for moderate recovery of these latest siphonotretids in late Eifelian is the matter of discussion. 


\section{Conclusions}

Organophosphatic brachiopods from the UDI confirm dramatic environmental changes at the latest Eifelian in the Prague Basin. Thermal expansion of ocean at the Kačák Event led to extension of oxygen reduced environment over previously shallow-water reef environment in the Koněprusy area. This sea lever rise drew out the deep water and hypoxic (Orbaspina, Paterula) and likely epiplanktonic (Opatrilkiella, Opsiconidion) (Mergl \& Vodrážková 2012) lingulates over formerly much shallower environment during onset of the Kačák Event (Polygnathus ensensis Zone). Assuming from available field data some lingulates (Paterula, Orbaspina) had their last existence in the marine ecosystem of the Kačák Event (Polygnathus ensensis Zone). Unlike to them, the genus Lingulipora emerged before onset of the Kačák Event. It is known in the Tortodus kockelianus Zone, but the Kačák Event with oxygen reduced environment triggered subsequent expansion of this genus over the shelves of Rheic Ocean and adjacent parts of Laurussia.

\section{Acknowledgements}

The author is greatly indebted to J. Nebesářová, J. Vaněček, and T. Bílý (Academy of Science of the Czech Republic, České Budějovice) for help with SEM study and to S. Vodrážková (Czech Geological Survey) for supply by conodont data. This study was supported by grant of the Grant Agency of the Czech Republic (GACR grant No. 17-18120S).

\section{References}

Alberti, G.K.B. 1987. Tentaculites (Dacryoconarida) und Trilobiten aus den Wissenbacher Schiefern und aus dem Ballerbacher Kalk (Devon, Rheinisches Schiefergebirge). Neues Jahrbuch für Geologie und Paläontologie, Monatshefte 5, 257-266.

BALIŃSKI, A. 1979. Brachiopods and conodonts from the Frasnian of the Debnik anticline, southern Poland. Palaeontologia Polonica 39, 3-95.

BALIŃski, A. 1988. Shell morphology and structure of Lingulipora Girty. Acta Palaeontologica Polonica 33, 123-133.

BALIŃSKI, A. 1997. Evolution of embryopnic development in lingulid brachiopods. Acta Palaeontologica Polonica 42, 45-56.

Baliński, A. 2001. Embryonic shell of Devonian linguloid brachiopods. In Brunton, C.H.C., Cocks, L.R. \& Long, S. (eds) Brachiopods past and present. The systematic Association Special Volume 63, 91-101.

BAliński, A. \& Holmer, L.E. 1999. The Late Devonian trematid lingulate brachiopod Schizobolus from Poland. Acta Palaeontologica Polonica 44, 335-346.

Barrande, J. 1847. Ueber die Brachiopoden der silurischen
Schichten von Böhmen. I. Teil. Naturwissenschaftliche Abhandlungen 2, 337-475.

Barrande, J. 1848. Ueber die Brachiopoden der silurischen Schichten von Böhmen. II. Teil. Naturwissenschaftliche Abhandlungen 2, 155-256.

Barrande, J. 1852. Systême silurien du centre de la Bohême. I. Trilobites. 1100 pp. Privately published, Prague \& Paris.

Barrande, J. 1879. Systême silurien du centre de la Bohême. Iére partie. Recherches paléontologiques. Vol. 5. Classe des Mollusques. Ordre des Brachiopodes. 226 pp. Privately published, Prague \& Paris.

Berkyová, S. 2004. Middle Devonian Tentaculitoidea from the late generation of fillings of the neptunian dyke in the Koněprusy area (Prague Basin, Czech Republic). Journal of the Czech Geological Society 49(3-4), 147-155.

BoučEK, B. 1964. The Tentaculites of Bohemia. 215 pp. Academia, Praha.

Boucot, A.J. 1975. Evolution and extinction rate controls. 427 pp. Elsevier, Balkema.

BoučEK, B. \& Prantl, F. 1959. Význam tentakulitů pro stratigrafii středočeského devonu. Časopis Národního muzea, řada př́rodovédná $128,5-7$.

Brock, G.A., Engelbretsen, M.J. \& Dean-Jones, G. 1995. Acrotretoid brachiopods from the Devonain of Victoria and New South Wales. Memoires of the Association of Australasian Palaeontologists 18, 105-120.

BRoderiP, W.J. 1833. Description of some species of Cuvier's family Brachiopoda. Zoological Society of London, Proceedings 1, 141-144.

Budil, P. 1995. Demonstration of the Kačák event (Middle Devonian, uppermost Eifelian) at some Barrandian localities. Věstník Českého geologického ústavu 70(4), 1-24.

Chlupáč, I. 1955. Stratigraphical study of the oldest Devonian beds of the Barrandian. Sborník Ústředního ústavu geologického, oddíl geologický 21(2), 91-224.

Chlupáč, I. 1956. Nové poznatky o stratigrafii středočeského devonu. Věstnik Ústředního ústavu geologického 31, 233-243.

Chlupéč, I. 1957. Facial development and biostratigraphy of the Lower Devonian of Central Bohemia. Sbornik Ústředniho ústavu geologického, oddíl geologický 23, 369-485.

Chlupáč, I. 1959. Facial development and biostratigraphy of Daleje Shales and Hlubočepy Limestones (Eifelian) in the Devonian of Central Bohemia. Sborník Ústředního ústavu geologického, oddíl geologický 24, 446-511.

Chluṕ́č, I. 1983. Trilobite assemblages in the Devonian of the Barrandian area and their relations to palaeoenvironments. Geologica et Palaentologica 17, 43-73.

ChlupÁČ, I. 1984. Devon Zlatého koně. Český Kras 9, 17-27.

ChlupéČ, I. 1996. Neptunian dykes in the Koněprusy Devonian: Geological and palaeontological observations. Věstník Českého geologického ústavu 71(3), 193-208.

ChlupÁC̆, I. 1998a. K faciím a stratigrafii spodnodevonského útesového komplexu u Koněprus. Věstník Českého geologického ústavu 73(1), 1-13.

Chlupáč, I. 1998b. Devonian, 101-133. In Chlupáč, I., HavlíČEK, V., KŘíž, J., KuKal, Z. \& ŠTorch, P. (eds) Palaeozoic of 
the Barrandian (Cambrian to Devonian). Czech Geological Survey, Prague.

Chlupáč, I. 2003. Comments on facies development and stratigraphy of the Devonian, Barrandian area, Czech Republic. Bulletin of Geosciences 78(4), 299-312.

Chlupáč, I. \& Turek, V. 1983. Devonian goniatites from the Barrandian area, Czechoslovakia. Rozpravy Ústředního ústavu geologického 46, 1-159.

Chlupéč, I., Havlíček, V., Ǩ̌íž, J., Kukal, Z. \& Štorch, P. 1998. Palaeozoic of the Barrandian (Cambrian to Devonian). 183 pp. Czech Geological Survey, Prague.

Cocks, L.R.M. \& Torsvik, T.H. 2002. Earth geography from 500 to 400 million years ago: a faunal and palaeomagnetic review. Journal of the Geological Society of London 159, 631-644. DOI 10.1144/0016-764901-118

Cooper, G.A. 1956. Chazyan and related brachiopods. Smithsonian Miscellaneous Collection 127, 1-1245.

Cooper, G.A. \& Dutro, J.T. 1982. Devonian brachiopods of New Mexico. Bulletins of American Paleontology 82-83(313), 1-215.

Davidson, T. 1848. Mémoire sur les brachiopodes du Système silurien supérieur de l'Angleterre. Bulletin de la Société géologique de France, série 2, 5, 309-338, 370-374.

Galle, A. 1994. Rugose corals of the Acanthopyge Limestone of Koněprusy (Middle Devonian, Barrandian, Czech Republic). Věstník Českého geologického ústavu 69, 41-58.

Galle, A. \& Hladil, J. (eds) 1991. Lower Paleozoic corals of Bohemia and Moravia. Excursion Guidebook B3VI. International Symposium on Fossil Cnidaria including Archeaeocyatha and Porifera. 83 pp. Westfälischen Wilhelms Universität, Münster.

GiRTY, G.H. 1898. Description of a fauna found in the Devonian black shale of eastern Kentucky. American Journal of Science (series 4) 6, 384-395.

GraY, J.E. 1840. Synopsis of the contents of the British Museum, $42^{\text {th }}$ edition. 370 pp. British Museum, London.

HaLl, J. 1843. Geology of New York 4. Comprising the Survey of the fourth Geological District. 683 pp. New York Geological Survey, Albany, New York.

HavlíčeK, V. \& Kukal, Z. 1990. Sedimentology, benthic communities, and brachiopods in the Suchomasty (Dalejan) and Acanthopyge (Eifelian) Limestones of the Koněprusy area (Czechoslovakia). Sborník geologických véd, Paleontologie 31, 105-205.

HAVlíčEK, V. \& VANĚK, J. 1996. Brachiopods and trilobites in the Chýnice Limestone (Emsian) at Bubovice (Čeřinka hillside; Prague Basin). Palaeontologica Bohemiae 2, 1-16.

Havlíček, V., VaněK, J. \& FatKa, O. 1994. Perunica microcontinent in the Ordovician (its position within the Mediterranean Province, series division, benthic and pelagic associations). Sborník geologických věd, Geologie 46, 23-56.

HLADIL, J. 1993. Tabulatomorphs and stromatoporoids below and above the upper boundary of the Acanthopyge Limestone (Eifelian/Givetian transition interval, Central Bohemia). Věstník Českého geologického ústavu 68(2), 27-42.

HLADIL, J. 1995. Basic information about the sedimentology and diagnesis of the Koněprusy Reef (Lower Devonian, Pragian,
SW segment of the Central Barrandian synform). Fossil Cnidaria \& Porifera 24(1A), 26-41.

Hladil, J., Beroušek, P. \& Lukeš, P. 1992. Temné vápencové vrstvy při stropu akantopygových vápenců u Koněprus otomari-Kačák event. Zprávy o geologických výzkumech v roce 1991, 53-55.

Hladil, J., Galle, A., Zikmundová, J., Kalvoda, J. \& BeroušEK, P. 1991. Stop B3-4, Acanthopyge Limestone of the Koněprusy area. Červený lom, Preisslerův lom and Jiráskův lom, 20-23, 26-29. In Galle, A. \& Hladil, J. (eds) Lower Paleozoic corals of Bohemia and Moravia. Excursion Guidebook B3. VI. International Symposium on Fossil Cnidaria including Archaeocyatha and Porifera. Westfälischen Wilhelms Universität, Münster.

Holmer, L.E. 1989. Middle Ordovician phosphatic inarticulate brachiopods from Västergötland and Dalarna, Sweden. Fossils and Strata 26, 1-172.

Holmer, L.E. \& Popov, L.E. 2000. Lingulata, 30-146. In Williams, A., Brunton, C.H.C., Carlson, S.J. et al. (eds) Treatise on Invertebrate Paleontology, part H, Brachiopoda, Revised, Volume 2. Geological Society of America Inc. and The University of Kansas, Boulder, Lawrence.

KalvodA, J. 1992. The youngest conodont fauna of the Barrandian. Scripta 22, 61-63.

Kunn, O. 1949. Lehrbuch der Paläozoologie. 326 pp. Schweizerbart, Stuttgart.

KUKAL, Z. \& JäGER, O. 1988. Siliciclastic signal of the Variscan orogenesis: The Devonian Srbsko Formation of Central Bohemia. Věstník Ústředního ústavu geologického 63, 65-81.

Kutorga, S.S. 1848. Ueber die Brachiopoden-familie der Siphonotretaceae. Russisch-Kaiserliche Mineralogische Gesellschaft zu St. Petersbourg, Verhandlungen 1847, 250-286.

LENZ, A.C. 1993. A Silurian sponge-inarticulate brachiopod life? association. Journal of Paleontology 67, 138-139. DOI 10.1017/S0022336000021259

Ludvigsen, R. 1974. A new Devonian acrotretid (Brachiopoda, Inarticulata) with unique protegular ultrastructure. Neues Jahrbuch für Geologie und Paläontologie, Monatshefte 3, 133-148.

Menke, C.T. 1828. Synopsis methodica molluscorum generum omnium et specierum earum quae in Museo Menkeano adservantur. 91 pp. G. Uslar, Pyrmonti.

Mergl, M. 1999. Genus Paterula (Brachiopoda) in Ordovician-Silurian sequence of Central Bohemia. Věstník Českého geologického ústavu 74(3), 347-361.

Mergl, M. 2001a. Lingulate brachiopods of the Silurian and Devonian of the Barrandian. Acta Musei nationalis Pragae, Series B-Historia Naturalis 57, 1-49.

Mergl, M. 2001b. Extinction of some lingulate brachiopod families: new stratigraphical data from Silurian and Devonian from Bohemia, 345-351. In BRunton, C.H.C., Cocks, L.R.M. $\&$ Long, S. (eds) Brachiopods past and Present. Systematic Association Special Volume 63.

Mergl, M. 2002. Linguliformean and craniiformean brachiopods of the Ordovician Třenice to Dobrotivá Formations) of the Barrandian, Bohemia. Acta Musei Nationalis Pragae, series BHistoria Naturalis 58(1-2), 1-82. 
Mergl, M. 2003. Orbaspina chlupaci sp. nov., a new siphonotretid brachiopod from the Silurian of the Barrandian area, Bohemia. Bulletin of Geosciences 78, 419-421.

Mergl, M. 2008. Lingulate brachiopods from the Acanthopyge Limestone (Eifelian) of the Barrandian, Czech, Republic. Bulletin of Geosciences 83(3), 281-298. DOI 10.3140/bull.geosci.2008.03.281

Mergl, M. 2014. The first occurrence of the Devonian rugose coral Calceola sandalina (Linné, 1771) in the Barrandian area, Czech Republic. Folia Musei Rerum Naturalium Bohemiae Occidentalis, Geologica et Paleobiologica 48, 11-19.

Mergl, M. 2015. Fenestrate bryozoans in the Acanthopyge Limestone (Eifelian) in the Barrandian area (Czech Republic). Folia Musei Rerum Naturalium Bohemiae Occidentalis, Geologica et Paleobiologica 49, 9-15.

Mergl, M. \& Ferrová, L. 2009. Lingulate brachiopods from the Chýnice Limestone (upper Emsian, Barrandian; Czech Republic). Bulletin of Geosciences 84(3), 525-546. DOI 10.3140/bull.geosci.1143

Mergl, M. \& Jiménez-SÁncheZ, A. 2015. Lingulate brachiopods from the Suchomasty Limestone (upper Emsian) of the Barrandian, Czech Republic. Bulletin of Geosciences 90(1), 173-193. DOI 10.3140/bull.geosci.1533

Mergl, M. \& VodrÁžKovÁ, S. 2012. Emsian-Eifelian lingulate brachiopods from the Daleje-Třebotov Formation (Třebotov and Suchomasty limestones) and the Choteč Formation (Choteč and Acanthopyge limestones from the Prague Basin; the Czech Republic). Bulletin of Geosciences 87(2), 315-332. DOI 10.3140/bull.geosci.1298

Mergl, M., Frýda, J. \& Kubajko, M. 2018. Response of organophosphatic brachiopods to the mid-Ludfordian (late Silurian) carbon isotope excursion and associated extinction events in the Prague Basin (Czech Republic). Bulletin of Geosciences 93(3), 369-400. DOI 10.3140/bull.geosci.1710

Mergl, M., VašKaninová, V. \& Žıgaite, Ž. 2017. Vertebrate microremains from the Pragian, Emsian and Eifelian of the Prague Basin (Czech Republic). Folia Musei Rerum Naturalium Bohemiae Occidentalis, Geologica et Paleobiologica 51(1-2), 1-12. DOI 10.1515/fbgp-2017-0001

Milne-Edwards, H. \& Haime, J. 1851. Monographie des polypiers fossiles des terrains paleozoïques. Archives $d u$ Muséum d'Histoire Naturelle 5, 1-502.

Morzadec, P.M., Mergl, M., Villarroel, C., Janvier, P. \& Racheboeuf, P.R. 2015. Trilobites and inarticulate brachiopods from the Devonian Floresta Formation of Colombia: a review. Bulletin of Geosciences 90, 331-358. DOI 10.3140/bull.geosci.1515

NovÁK, O. 1890. Vergleichende Studien an einigen Trilobiten auf dem Herzyn von Bicken, Wildungen, Greifenstein und Böhmen. Palaeontologische Abhandlungen, Neue Folge, 1(3), 95-138.

Obrhel, J. 1961. Die Flora der Srbsko-Schichten (Givet) des mittelböhmischen Devons. Sborník Ústředního ústavu geologického, oddil paleontologický 26, 7-46.

Obrhel, J. 1968. Die Silur und Devonflora des Barrandiums. Paläontologische Abhandlungen, Abt. B 2(4), 635-703.

Orbigny, A. D' 1847. Considérations zoologiques et géologiques sur les Brachiopodes ou Palliobranches. Comptes Rendus Hebdomodaires des Séances de l'Académie des Sciences 25, 193-195, 266-269.

Schuchert, C. 1893. Classification of the Brachiopoda. American Geologist 11, 141-167.

Stampfli, G.M, Raumer, J.F. \& Borel, G.D. 2002. Paleozoic evolution of pre-Variscan terranes: From Gondwana to the Variscan collision. Geological Society of America Special Paper 364, 263-280.

Sutton, M.D., Bassett, M.G. \& Cherns, L. 2000. Lingulate brachiopods from the lower Ordovician of the Anglo-Welsh Basin. Part. 2. Monograph of the Palaeontological Society 154, 61-114.

Svoboda, J. \& PrantL, F. 1949. Stratigraficko-tektonická studie o devonské oblasti koněpruské. Sborník Státního geologického ústavu Českoskovenské republiky 16, 5-92.

Ulrich, E.O. 1886. Description of new Silurian and Devonian fossils. American Paleontology, Contributions 1, 3-35.

Valentine, J. \& Brock, G.A. 2003. A new siphonotretid brachiopod from the Silurian of Central-Western New South Wales, Australia. Records of the Australian Museum 55, 231-244. DOI 10.3853/j.0067-1975.55.2003.1378

WaAgen, W. 1885. Salt Range fossils, I. Productus-Limestone fossils, Brachiopoda. Memoirs of the Geological Survey of India, Palaeontologica Indica (series 13) 4(5), 729-770.

Willard, B. 1928. The brachiopods of the Ottosee and Holston formations of Tennessee and Virginia. Bulletin of the Harvard Museum of Comparative Zoology 68, 255-292.

ŽÁk, J. \& SlÁmA, J. 2018. How far did the Cadomian 'terranes' travel from Gondwana during early Palaeozoic? A critical reappraisal based on detrital zircon geochronology. International Geology Review 60(3), 319-338.

DOI 10.1080/00206814.2017.1334599

Zikmundová, J. \& Kalvoda, J. 1991. Provisional list of conodonts, 24-25. In Galle, A. \& Hladil, J. (eds) Lower Paleozoic corals of Bohemia and Moravia. Excursion Guidebook B3. VI. International Symposium on Fossil Cnidaria including Archaeocyatha and Porifera. Westfälischen Wilhelms Universität, Münster. 